\title{
Jean-Baptiste Charcot in Rio de Janeiro: glamorous trip and celebrity in 1908
}

\author{
Jean-Baptiste Charcot no Rio de Janeiro: celebridade e glamour em 1908 \\ Hélio A. G. Teive', Renato P. Munhoz², Plínio G. de Lima ${ }^{1}$, Francisco M. B. Germiniani ${ }^{1}$
}

\begin{abstract}
The authors review the visit of Commander Charcot and the crew of his ship, the "Pourquoi Pas?", to Rio de Janeiro, Brazil, in 1908, where he stayed for eight days, while en-route as part of the second French expedition to the Antarctic. It was a glamorous stay as Commander Charcot was treated as a true star and international celebrity, befitting his position.
\end{abstract}

Keywords: neurology, maritime explorer, Rio de Janeiro, Jean-Baptiste Charcot.

\section{RESUMO}

Revisamos a estadia de oito dias do Comandante Jean-Baptiste Charcot e a tripulação do seu navio "Pourquoi Pas?" no Rio de Janeiro, em 1908, durante a segunda expedição francesa para a Antártica. A estadia do Comandante Charcot foi um acontecimento social e o mesmo foi recebido com honrarias dignas de uma celebridade internacional.

Palavras-chave: neurologia, explorador marítimo, Rio de janeiro, Jean-Baptiste Charcot.

Jean-Baptiste Charcot (1867-1936) was a neurologist who trained at the Salpêtrière school, in Paris, France, under the supervision of Professor Jean-Martin Charcot, his own father, and his other pupils ${ }^{1,2}$. Following Professor Charcot's death, Jean-Baptiste Charcot decided to give up not only Neurology, but also Medicine as a whole and began a career as a maritime explorer, which had been his childhood's dream ${ }^{1,2,3}$. Initially he decided to explore the polar regions, beginning with the Arctic Circle. After that he was enrolled as part of the project known as The French Antarctic Expedition, thus starting his activities as a maritime explorer of the South Pole ${ }^{3,4}$. The first expedition to the Antarctic polar ice cap took place in the years of 1903-1905, while the second expedition was on a ship nicknamed the "Pourquoi Pas?" during the years $1908-1910^{3.4}$. At that time Jean-Baptiste Charcot had already gained an expressive worldwide reputation, becoming a true star, known throughout as Commander Charcot ${ }^{3.4}$. The aim of this paper is to make a historical account of Commander Jean-Baptiste Charcot's eight-day stay in Rio de Janeiro in 1908.

\section{THE CHARCOTS' AND BRAZIL}

Professor Jean-Martin Charcot (1825-1893), considered the father of Clinical Neurology, was arguably the most famous and respected professor of Neurology during the 19th century, worldwide renowned ${ }^{1,2}$. Professor Charcot happened to have established personal connections with Dom Pedro II, the Brazilian emperor, in both social and medical terms, as they were not only friends, but also had a patient-physician relationship $p^{2,5.6}$.

As a matter of fact, Dom Pedro II invited Professor Charcot to come to Brazil several times, but unfortunately Professor Charcot declined them time and again ${ }^{5.6}$. Nevertheless, Professor Charcot's son, the neurologist and maritime explorer Jean-Baptiste Charcot, visited Brazil twice, the first time in 1903 during the first expedition to the Antarctic Polar ice cap, when he made a stopover at Recife, Pernambuco ${ }^{3,4,7}$. In fact, that was a very short stop to replenish the water supply before continuing on his journey to Buenos Aires. The second time he visited Brazil was in 1908, during his second expedition to the Antarctic Polar ice cap, when both the captain and the crew of his ship, the aptly named "Pourquoi Pas?", stayed for eight days in Rio de Janeiro ${ }^{47}$.

\section{COMMANDER CHARCOT AND THE CREW OF THE "POURQUOI PAS?"IN RIO DE JANEIRO}

In 1908, Charcot's name was very well- known in Brazil, particularly in Rio de Janeiro, the Brazilian capital city at that

\footnotetext{
'Universidade Federal do Paraná, Hospital de Clínicas, Departamento de Medicina Interna, Serviço de Neurologia, Curitiba PR, Brazil;

¿University of Toronto, Toronto Western Hospital, Movement Disorders Centre, Toronto ON, Canada.

Correspondence: Hélio A. G. Teive; Rua General Carneiro, 1103/102; 80060-150 Curitiba PR, Brasil; E-mail: hagteive@mps.com.br

Conflict of interest: There is no conflict of interest to declare.

Received 19 August 2014; Received in final form 03 April 2015; Accepted 23 April 2015.
} 
time, making it both the country's most important city and a cultural hub. This was due in part to the fact that Professor Charcot, who had died in 1893, had a strong reputation in the field of medicine worldwide, particularly in neurology ${ }^{1,2,5}$. Regardless of his father's fame, Jean-Baptiste Charcot had made quite a name for himself as "Commander Charcot", a.k.a. the "Polar gentleman", the famous French maritime explorer of the Arctic and Antarctic Polar ice caps ${ }^{3,4,7}$. Commander Charcot and his crew's arrival in Rio was met with a mix of excitement, bewilderment and astonishment and the main periodicals of the time would describe the event in minute detail ${ }^{8,9,10}$. Jean-Baptiste Charcot and his crew arrived in Rio de Janeiro, on the $12^{\text {th }}$ October, 1908, aboard the "Pourquoi Pas?", they were received by members of the Brazilian government and the French community, headed by the vice-consul, Mr. EugèneCharlat. The Minister of Foreign Affairs, the Baron of Rio Branco, received the whole expedition at the Itamaraty Palace, the seat of government, and the Minister of Marine, Admiral Alexandrino de Alencar, visited the "Pourquoi Pas?" (Figure 1). Captain Barros Cobra granted the crew a special gift, a silk flag, which had been hand-embroidered by his own wife ${ }^{7}$. Following their arrival in Rio, the local periodicals would refer to the famous maritime explorer with a series of superlatives, such as "distinguished sage", "a soul born for Science", "an indomitable spirit”, "noted French scientist", and a "scientific hero" ${ }^{8,9,10}$.

The prospect of having Commander Charcot giving lecture on his journey to the South Pole was met with excitement, especially as he was to present at the time a novelty, an auto-sledge, dubbed "Margarida", that was to be used for the first time in his second expedition to Antartica ${ }^{8}$. During their eight-day stay in Rio de Janeiro, Commander Charcot, his second wife, Mrs. Jeanne Charcot, his daughter, and his crew enjoyed the kindness of the Brazilian people. The Brazilian Government provided them with coal to be used as fuel for

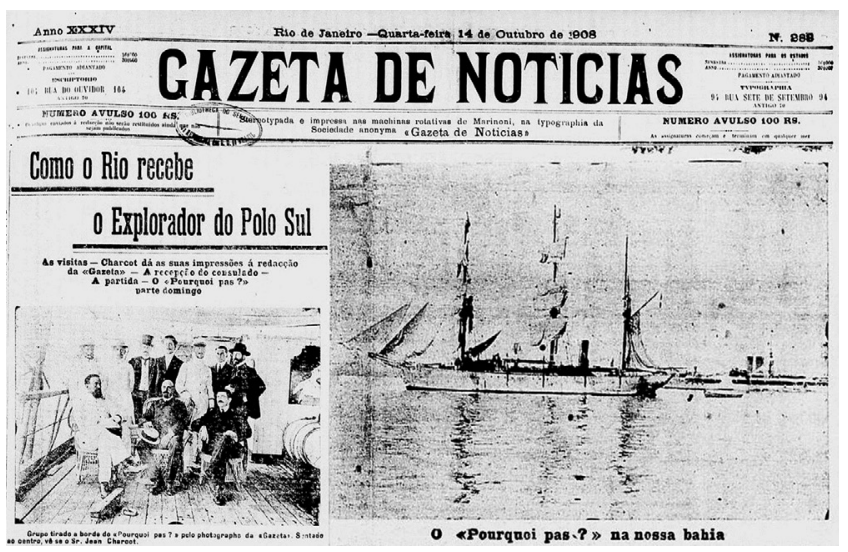

Figure 1. The Charcot Expedition - Rio de Janeiro, RJ, Brazil (Gazeta de Notícias, 14th October 1908). "The South Pole Explorer" and "The Pourquoi-pas?" stationed on Guanabara's bay. (Extracted from Hemeroteca Digital Brasileira - 26th December 2013). their trip to the South Pole and also made repairs to the ships external painting. Among the many gifts given to the crew of the "Pourquoi Pas?" there were coffee, yerba mate, 200 liters of spirits, cigars and cigarettes (Figure 2).

Commander Charcot and his family would visit a handful of Rio's most famous tourist attractions: the Tijuca's forest, the Botanical Gardens, the Pharoux docks and the Corcovado. The crew was invited to luncheons, dinners and exquisite banquets ${ }^{8,9,10}$. Commander Charcot, his family and the most important members of his crew were granted with a special lunch at the Corcovado, a banquet at the Itamaraty Palace, a dinner with the Baron of Rio Branco and a reception with the representatives of the French colony in Rio. He also visited several hospitals, including the Santa Casa of Rio and a leprosarium, and the Manguinhos Institute and lectured for different organisations, particularly the Geography Society, which made him a corresponding member $^{8,9,10}$. On 20th October 1908 he departed for Buenos Aires, Argentina ${ }^{7,8,9,10}$. Even months after the "Pourquoi Pas?"'s departure, Commander Charcot's remained a hot topic amid the Carioca society, to the point that during the Carnival of 1909, in February, both the Commander and the "Pourquoi Pas?" were homage with carnival blocks and a parade car of the "Sociedade dos Tenentes do Diabo" (the Devil's Lieutenants' Society) ${ }^{8,9,10}$.

In conclusion, Commander Charcot, his family and crew enjoyed a glamorous stay during their visit to Rio de Janeiro in 1908; with the Commander being treated as a true star and international celebrity.

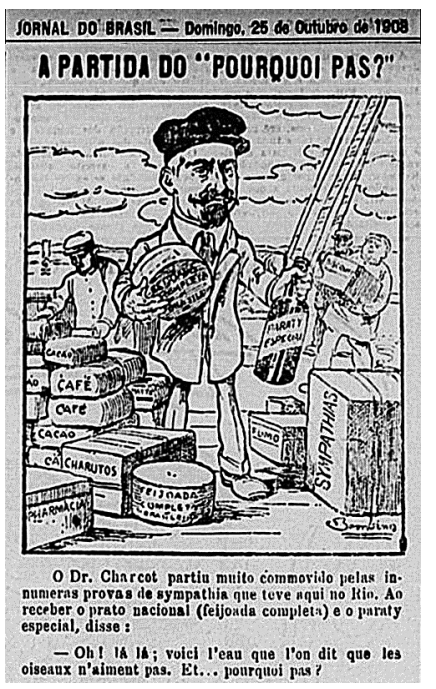

Figure 2. Caricature of Commander Jean-Baptiste Charcot on his departure with provisions he received as gifts, including feijoada and spirits (Paraty ${ }^{\circledR}$ ) published on the Jornal do Brasil on 25 th October 1908. "- Oh! Lá, lá; here's the water that birds do not drink. And... why not?" (Extracted from Hemeroteca Digital Brasileira - hemerotecadigital.bn.br - 26th December 2013). 


\section{References}

1. A Teive HAG, Almeida SM, Arruda WO, Sá DS, Werneck LC. Charcot and Brazil. Arq Neuropsiquiatr. 2001;59(2A):295-9. doi:10.1590/S0004-282X2001000200032

2. Teive HAG, Arruda WO, Werneck LC. Rosalie: the Brazilian female monkey of Charcot. Arq Neuropsiquiatr. 2005;63(3A):707-8. doi:10.1590/S0004-282X2005000400031

3. Teive HAG, Munhoz RP, Simões JC. Charcot's son, Commander Jean-Baptiste Charcot: from neurology to "Pourquoi Pas?". Arq Neuropsiquiatr. 2012;70(4):305-7. doi:10.1590/S0004-282X2012000400016

4. Teive HAG, Lima CFL, Lima PMC, Germiniani FMB, Munhoz RP. Jean-Baptiste Charcot and Brazil. Arq Neuropsiquiatr. 2014;72:640-2.

5. Goetz CG, Bonduelle M, Gelfand T. Charcot: constructing neurology. New York: Oxford University Press; 1995.
6.

Bailey PJ-M. Charcot: 1825-1893: his life- his work, Georges Guillain. New York: Paul B. Hoeber; 1959.

7. Charcot JB. The voyage of the "Why Not?"in the Antartic: the journal of the second French South Polar expedition, 1908-1910. Cambridge: Cambridge University Press; 1980.

8. Comandante Charcot no Brasil. Correio da Manhã (Rio de Janeiro). 1908 Sept./Oct. [cited 2013 Dec 26]. Available from: http://www. hemerotecadigital.bn.br. Página 1.

9. Como o Brasil recebe o explorador do Polo Sul. Gazeta de Notícias (Rio de Janeiro). 1908 Oct 14 [cited 2013 Dec 26]. Available from: http://www.hemerotecadigital.bn.br, Página 1.

10. A partida do "Porquois pas?". Jornal do Brasil (Rio de Janeiro) 1908 Oct 25 [cited 2013 Dec 26]. Available from: http://www. hemerotecadigital.bn.br. Página 1. 